\title{
The natural radioactivity in vicinity of the brown coal mine Tusnica - Livno, BiH
}

\author{
L. Saracevic, D. Samek, A. Mihalj and N. Gradascevic \\ Faculty of Veterinary Medicine, University Sarajevo, 71000 Sarajevo, \\ Bosnia and Herzegovina
}

\begin{abstract}
Coal mine Tusnica is located in South-West part of Bosnia and Herzegovina in the municipality Livno. Coal mine Tusnica consists of two surface coal mines. The first one is brown coal surface deposit called Drage and second one is lignite deposit called Table. The brown coal deposit shows increased levels of natural radionuclides. The highest absorbed dose rate is recorded in the center of the surface coal mine Tusnica-Drage $\left(500 \mathrm{nGy} \mathrm{h}^{-1}\right)$ as result of the increased content of uranium and radium in coal (average specific activity of U-238 is $623 \pm 23 \mathrm{~Bq} \mathrm{~kg}^{-1}$ and Ra-226 is $1191 \pm 5 \mathrm{~Bq} \mathrm{~kg}^{-1}$ ). Levels of natural radionuclides in the vicinity of the surface deposit Drage in agricultural soil (about $3 \mathrm{~km}$ of the centre mine) are slightly increased due to the use of the coal ash and coal dust for fertilization of the land (U-238 is $142 \pm 11 \mathrm{~Bq} \mathrm{~kg}^{-1}$ and $\mathrm{Ra}-226$ is $197 \pm 2 \mathrm{~Bq} \mathrm{~kg}^{-1}$ ). Obtained results in soil-plant-animal products chain does not show significantly increased levels of natural radionuclides due to the fact that mentioned radionuclides, in general, have a low transfer factors in soil-plant-animal products chain.
\end{abstract}

\section{INTRODUCTION}

Coal industry represents the potential dangerous source of radioactive contamination for environmental, especially in the cases of rising levels of natural radionuclides in primary ore. Many studies had been performed in order to explore the problem and to found parameters that could be used in risk assessment models [1-4]. The goal of this paper is to explore the impact of the coal mines Tusnica which has slightly rising levels of natural radionuclides ${ }^{238} \mathrm{U}$ and ${ }^{226} \mathrm{Ra}$ into acoount the risk for population and for environment.

\section{MATERIALS AND METHODS}

\subsection{Coal mines Drage and Table}

Coal mine Tusnica is placed in South-West part of Bosnia and Herzegovina in Livno municipality and it consisted of two surface coal mines. The first one is brown coal surface deposit called Drage and second one is lignite deposit called Table.

The surface coal mine Drage is located at the south-east part of the coal basin Livno. The region of the coal mine Drage is represented with slight hills, rising from $850 \mathrm{~m}$ to $950 \mathrm{~m}$ above the sea level. In the area of the mine, several creeks that are going deep into the soil can be found. The soil is fissured and non-watertight that makes easier the process of underground filtration of both creek water and rain. Thickness of the coal layer vary from $1 \mathrm{~m}$ to $12 \mathrm{~m}$ with the average of $9.5 \mathrm{~m}$. Yearly production of coal in this mine is around 30000 tons and almost all is for the purpose of coal burning power plant Kakanj. The presence of uranium was determined in Tusnica coal. A reserve has being estimated at 831.8 tons uranium.

Lignite deposit Table is located in the north-west part of the coal basin Livno. Table basin was periodically flooded, but that was partly controlled with the network of irrigation canals. Primary source of the coal is Pliocene sedimentary series that are comprised of argil, marl, sand and 19 different lignite 
layers. Morphologically, Table pit is flattened plate with the average height above the sea level of $710 \mathrm{~m}$. The biggest consumer of the produced lignite is the chemical industry factory "Natron" from Maglaj (around 5000 tons a year), with usage of 65\% (approximately) of total yearly production of Table mine.

Local inhabitants, living in the vicinity of the mine, often use the coal for heating of their households that can potentially increase the risk of radiation for this group. Also, winds have significant impact on the dispersion of the radioactive dust from the coal deposits to the surrounding areas. Furthermore, coal is also being used for the fertilization of gardens and orchards.

\subsection{Sampling strategy}

Isodose maps were created covering the regions around Drage mine $(2 \mathrm{~km} \times 1.5 \mathrm{~km})$ and Table mine $(4 \mathrm{~km} \times 5 \mathrm{~km})$. For estimating isodoses, Point Kriging Grid Method with Linear Variogram Model was used [5]. During the maps creation process, measurements were taken in accordance with the predetermined grid of locations. For the surrounding area of Drage mine, measurements were taken on 55 different locations, while Table mine participated with 28 locations. Measuring in both regions were include the surface mines, surrounding facilities, coal deposits, facility used for coal separation, and smaller living areas with permanent inhabitants. Soil samples were taken from depth of 0 to $15 \mathrm{~cm}$ and with $5 \mathrm{~m} \times 5 \mathrm{~m}$ the size of the area (composite sample was measured by combining 5 individual samples). Sampling process (soil, grass, vegetables, meat and milk) was done in 6 permanently inhabited micro-locations (individual households) in the both regions, twice a year (early summer and late fall) for the period of 3 years (2004-2007).

Samples of coal and coal dust for gamma spectrometry analysis were taken directly from both surface mines (seven samples for each mine), coal deposits (four samples each) and facilities for coal separation (four samples), twice a year (early summer and late fall) for the period of 3 years (2004-2007).

\subsection{Gamma spectrometry}

Measuring was performed on the background-protected coaxial detector p-type, vertical configuration "POP-TOP" model "GEM 30P4" relative efficiency $30 \%$ and resolution $1.85 \mathrm{keV}$ at $1.33 \mathrm{MeV}$ produced by EG\&G ORTEC.

The homogenised samples were transferred to 330 gram plastic containers (bottom diameter $8.5 \mathrm{~cm}$, top diameter $10 \mathrm{~cm}$, height $5 \mathrm{~cm}$ ) for gamma measurements and sealed for 12 weeks to ensure secular equilibrium between ${ }^{238} \mathrm{U}$ and ${ }^{234} \mathrm{Th}$, and radium and its radioactive progeny. The measurements of the specific activities are determined with a level of confidence of $95 \%(2 \sigma)$.

\subsection{Dose rate measuring}

Dose rates were measured at $1 \mathrm{~m}$ above ground with gamma dose rate meter LB-123 made by BERTHOLD, dose rate range $0.05 \mu \mathrm{Svh}^{-1}$ to $10 \mathrm{mSvh}^{-1}$, energy range $30 \mathrm{keV}$ to $1.2 \mathrm{MeV}( \pm 30 \%$ relative to Cs-137) and resolution $0.01 \mu \mathrm{Sv} \mathrm{h}^{-1}$. The results are showed with statistical error of $10 \%$.

\section{RESULTS}

Figure 1 shows isodose map of the region around Drage coal mine $(2 \mathrm{~km} \times 1.5 \mathrm{~km})$.

For estimating isodoses, Point Kriging Grid Method with Linear Variogram Model was used and the value of the coefficient of multiple determinations was $\mathrm{R}^{2}=0.00216$, that shows the good compliance between measured and fitted data. Minimum value of the measured dose rate was $96.00 \mathrm{nGy} \mathrm{h}^{-1}$, while the maximum dose rate was $500.00 \mathrm{nGy} \mathrm{h}^{-1}$. Mean of the measurement was $141.47 \mathrm{nGy} \mathrm{h}^{-1}$ with 


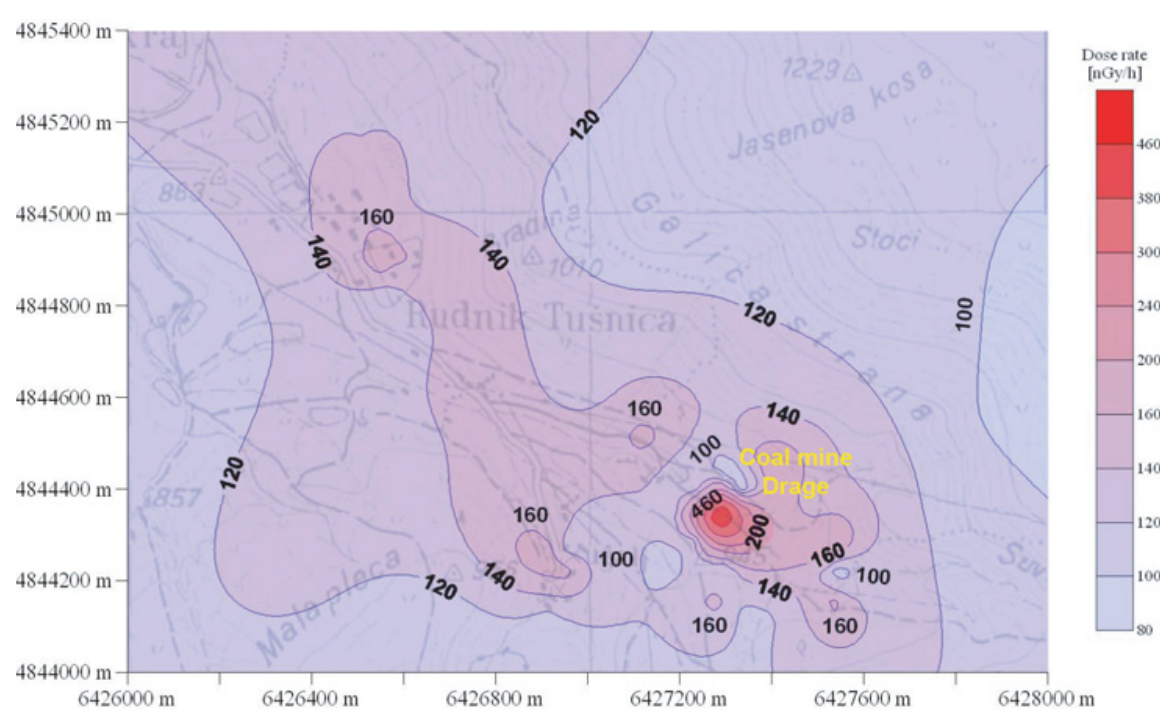

Figure 1. Isodose map of Drage region.

standard deviation of $54.22 \mathrm{nGy} \mathrm{h}^{-1}$. Values for median, lower quartile (25\%-tile) and upper quartile (75\%-tile) were at $131.00,114.00$ and $149.00 \mathrm{nGy} \mathrm{h}^{-1}$, respectively.

Ratio between the maximum and minimum of dose rate was 5.2, while the ratio of maximum and average dose rate was 3.5, which indicates the presence of points with increased dose rate ("hot spots"). However, ratio between upper quartile (75\% of the values are smaller than this number) and the minimum of measured dose rate was 1.6. Ratio between upper quartile and lower quartile (25\% of the values are smaller than this number) was 1.3 which indicates that there were no significant variations for the region as a whole.

The highest absorbed dose rate is recorded in canter of the surface coal mine $\left(500 \mathrm{nGy} \mathrm{h}^{-1}\right)$ as result of the increased content of uranium and radium in coal. Increasing of the absorbed dose rate is recorded in the area in which coal layer is placed close to the surface of the ground. The second highest dose rate is recorded at separation point $175 \mathrm{nGy} \mathrm{h}^{-1}$ and third one is measured at few points close to household $167 \mathrm{nGy} \mathrm{h}^{-1}$. Outside the area, absorbed dose rate is relatively close to the background value for that region [6].

The worst case scenario is that the estimated effective dose of outside irradiation for the workers around Drage mine is $0.616 \mathrm{mSv}$, while the workers performing the coal separation estimates are at $0.215 \mathrm{mSv}$, including effective yearly dose of $0.05 \mathrm{mSv}$ caused by cosmic radiation.

Isodose map of the lignite mine Table $(4 \mathrm{~km} \times 5 \mathrm{~km})$ was created by using the same methodology as the map for Drage mine, with $\mathrm{R}^{2}=0.13737$ (Figure 2). Minimum absorbed dose rate was $88.00 \mathrm{nGy} \mathrm{h}^{-1}$, while the maximum was at $158.00 \mathrm{nGy} \mathrm{h}^{-1}$. Mean of the absorbed dose rate was $117.00 \mathrm{nGy} \mathrm{h}^{-1}$, with standard deviation of $14.69 \mathrm{nGy} \mathrm{h}^{-1}$. Values for median, lower quartile $(25 \%$ tile) and upper quartile (75\%-tile) were as follows: $123.00,105.00$, and $131.00 \mathrm{nGy} \mathrm{h}^{-1}$. Ratio between maximum and minimum absorbed dose rate was 1.8 , while it had the value of 1.3 between maximum absorbed dose rate and average absorbed dose rate. Absorbed dose rate in this area is significantly lower than dose rate recorded in area of surface coal mine Drage, because of the fact that lignite mined in this deposit show lower content of uranium and radium. The highest value is recorded at separation point with value of $158 \mathrm{nGy} \mathrm{h}^{-1}$. Spread of the radioactivity in vicinity of the mine might also be caused by the wind which is a significant factor in this area. Estimated effective dose of external irradiation for the workers around the mine is $0.151 \mathrm{mSv}$, while the workers performing the coal separation estimates are at $0.194 \mathrm{mSv}$. 


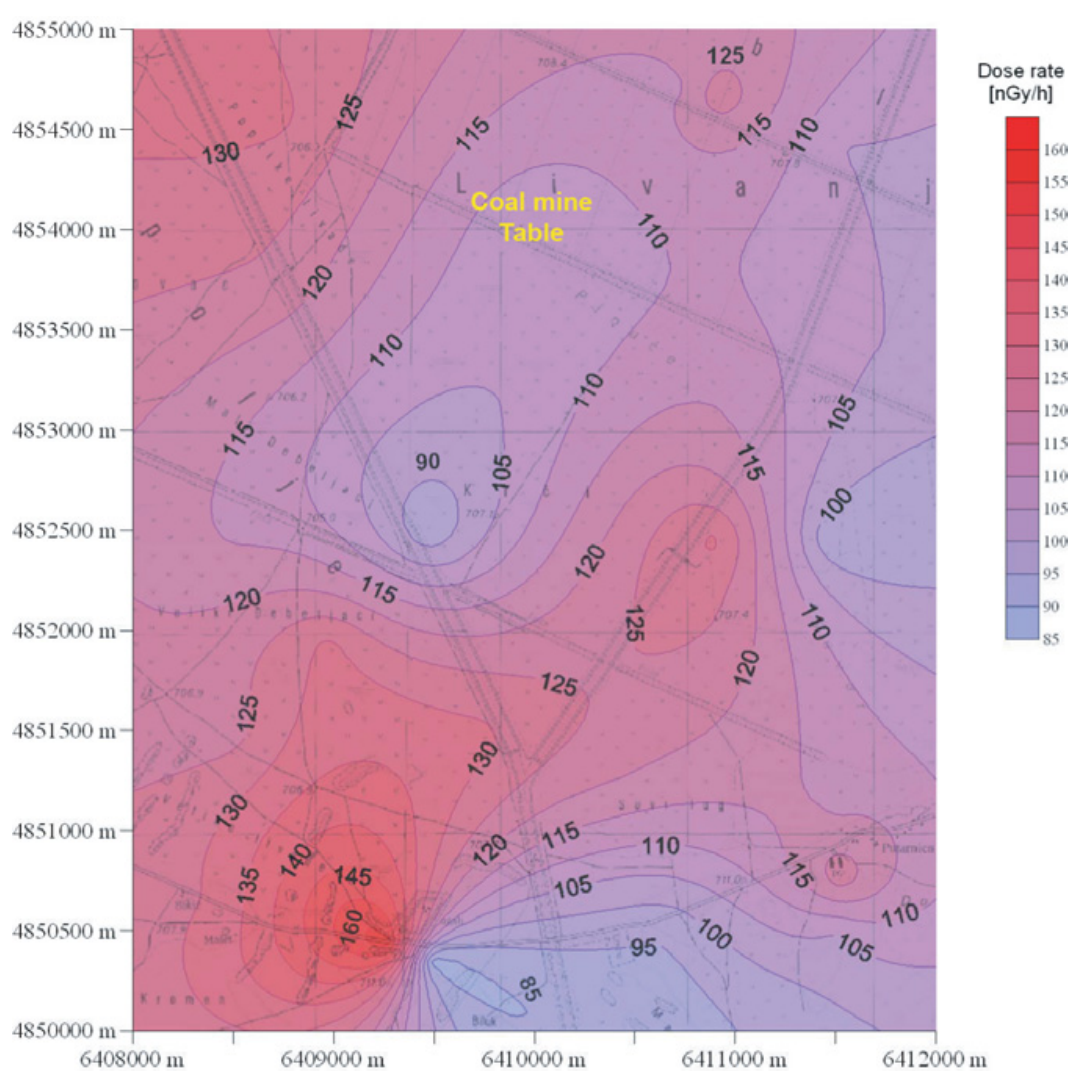

Figure 2. Isodose map of the Table mine region.

In Tables 1 and 2, we can find average activities for brown coal and surface soil layer for Drage and Table mines, respectively.

Table 1. Specific activity of brown coal and surface soil layer in coal mine Drage $\left(\mathrm{Bq} \mathrm{kg}^{-1}\right)$.

\begin{tabular}{|l|c|c|}
\hline Radionuclide & Brown coal & Surface soil layer \\
\hline U-235 & $28.68 \pm 1.07$ & $1.27 \pm 0.21$ \\
\hline U-238 & $623.03 \pm 23.32$ & $27.61 \pm 4.47$ \\
\hline Th-232 & $26.67 \pm 1.86$ & $17.69 \pm 0.80$ \\
\hline Ra-226 & $1191.34 \pm 4.83$ & $37.16 \pm 0.75$ \\
\hline K-40 & $32.92 \pm 7.20$ & $89.35 \pm 3.39$ \\
\hline
\end{tabular}

Table 2. Specific activity of lignite coal and surface soil layer in coal mine Table $\left(\mathrm{Bq} \mathrm{kg}^{-1}\right)$.

\begin{tabular}{|l|c|c|}
\hline Radionuclide & Lignite coal & Surface soil layer \\
\hline U-235 & $9.01 \pm 0.55$ & $2.54 \pm 0.33$ \\
\hline U-238 & $195.60 \pm 11.94$ & $55.12 \pm 7.15$ \\
\hline Th-232 & $11.54 \pm 1.04$ & $29.58 \pm 0.96$ \\
\hline Ra-226 & $263.33 \pm 2.43$ & $101.43 \pm 1.32$ \\
\hline K-40 & $137.64 \pm 6.06$ & $417.59 \pm 7.99$ \\
\hline
\end{tabular}

The obtained average activities of the natural radionuclides in the coal ash Drage are as follows: ${ }^{238} \mathrm{U} 1945 \pm 42,{ }^{232} \mathrm{Th} 41 \pm 8,{ }^{226} \mathrm{Ra} 1869 \pm 8$ and ${ }^{40} \mathrm{~K} 117 \pm 13 \mathrm{~Bq} \mathrm{~kg}^{-1}$, and for coal ash Table: ${ }^{238} \mathrm{U} 505 \pm 18,{ }^{232} \mathrm{Th} 18 \pm 2,{ }^{226} \mathrm{Ra} 555 \pm 4$ and ${ }^{40} \mathrm{~K} 109 \pm 6 \mathrm{~Bq} \mathrm{~kg}{ }^{-1}$. 
Average values for basic physio-chemical parameters of agricultural soil samples from Tusnica basin were: $\mathrm{Ph}$ 7.77, Humus $6.1 \%$, Humidity $4.87 \%$, Minerals $76.67 \%$ and Organic matter $18.46 \%$, with predominantly clay base. Average levels of natural radionuclide in agricultural soil samples Livno basin were: ${ }^{238} \mathrm{U} 142 \pm 11,{ }^{232} \mathrm{Th} 40 \pm 2,{ }^{226} \mathrm{Ra} 197 \pm 2$ and ${ }^{40} \mathrm{~K} 259 \pm 7 \mathrm{~Bq} \mathrm{~kg}^{-1}$.

Table 3. Average specific activity of plants and agricultural products $\left(\mathrm{Bq} \mathrm{kg}^{-1}\right)$.

\begin{tabular}{|l|c|c|r|}
\hline Sample & U-238 & Ra-226 & \multicolumn{1}{|c|}{ K-40 } \\
\hline Grass & $0.30 \pm 0.08$ & $0.57 \pm 0.13$ & $208.00 \pm 10.10$ \\
\hline Hay & $1.10 \pm 0.30$ & $2.30 \pm 0.60$ & $431.40 \pm 18.20$ \\
\hline Corn Stalk & $0.20 \pm 0.06$ & $0.42 \pm 0.10$ & $123.80 \pm 14.10$ \\
\hline Corn & $0.20 \pm 0.07$ & $0.40 \pm 0.12$ & $86.90 \pm 16.60$ \\
\hline Bean & $0.03 \pm 0.01$ & $0.06 \pm 0.01$ & $420,30 \pm 14.20$ \\
\hline Potato & $0.03 \pm 0.01$ & $0.05 \pm 0.01$ & $178.90 \pm 12.90$ \\
\hline Turnip & $0.10 \pm 0.03$ & $0.30 \pm 0.08$ & $83.20 \pm 03.50$ \\
\hline Onion & $0.03 \pm 0.01$ & $0.05 \pm 0.01$ & $68.10 \pm 14.20$ \\
\hline Lettuce & $0.20 \pm 0.06$ & $1.12 \pm 0.18$ & $238.50 \pm 12.20$ \\
\hline Cabbage & $0.06 \pm 0.02$ & $0.12 \pm 0.04$ & $73.72 \pm 10.70$ \\
\hline Pumpkin & $0.03 \pm 0.01$ & $0.04 \pm 0.01$ & $74.80 \pm 11.20$ \\
\hline
\end{tabular}

Table 4. Average specific activity of meat and animal products $\left(\mathrm{Bq} \mathrm{kg}^{-1}\right)$.

\begin{tabular}{|l|c|c|r|}
\hline Sample & U-238 & Ra-226 & \multicolumn{1}{|c|}{ K-40 } \\
\hline Cow milk & $0.014 \pm 0.006$ & $0.040 \pm 0.010$ & $46.210 \pm 6.200$ \\
\hline Cow cheese & $0.040 \pm 0.010$ & $0.080 \pm 0.020$ & $35.200 \pm 5.120$ \\
\hline Eggs & $0.310 \pm 0.080$ & $0.820 \pm 0.200$ & $62.460 \pm 4.860$ \\
\hline Chicken meat & $1.630 \pm 0.300$ & $5.720 \pm 1.240$ & $103.300 \pm 9.940$ \\
\hline Sheep milk & $0.030 \pm 0.010$ & $0.070 \pm 0.020$ & $39.200 \pm 4.120$ \\
\hline Sheep meat & $0.015 \pm 0.007$ & $0.021 \pm 0.008$ & $87.800 \pm 7.500$ \\
\hline
\end{tabular}

Table 3 and Table 4 show average specific activities for plants, agricultural, meat and animal products from the sampled micro locations (individual households). More significant increase of radium and uranium activity, compared to the average values in the world [7], was found in hay and chicken meat, which was most probably caused by the concentration of radionuclide during the drying of hay and by specific eating habits in animals (picking food and eating from soil surface). Average dose taken in through ingestion from the above mentioned agricultural products, meat and animal products is $0.412 \mathrm{mSv}$.

\section{CONCLUSIONS}

Brown coal mine Drage shows the highest levels of uranium and radium among all coals used in Bosnia and Herzegovina. Increased levels of uranium and radium in coal samples are not followed by increased levels of the radionuclides in surface soil layer. Level of natural radionuclides in agricultural soil are slightly increased due to the use of the coal ash and coal dust for fertilization of the land.

Levels of uranium and radium in coal samples from lignite surface coal mine Table do not show significant increase. Levels of uranium and radium in surface soil layer are higher than those obtained from the surface deposit Drage, probably due to the increased content of coal in soil samples.

Obtained results do not show significant increase of natural radionuclides in samples of agricultural and animal samples.

\section{Acknowledgments}

This study was financially supported by $6^{\text {th }}$ European Framework Programme, Contract No. INCO-CT-2004509214, project title "Assessment of the environmental risk for use of radioactively contaminated industrial tailings". 


\section{References}

[1] H.A. Amer, S. Shawky, M.I. Hussein, M.L. Abd El-Hady, J. Environ. Monit. 4, 583-587 (2002)

[2] H. Bem, P. Wieczorkowski, M. Budzanowski, J. Environ. Radioactivity 61, 191-201 (2002).

[3] M. Manolupoulou and C. Papastefanou, J. Environ. Radioactivity 16, 261-271 (1992).

[4] C. Papastefanou and S. Charalambous, Health Phys. 46, 293-302 (1984).

[5] N.A.C. Cressie, Mathematical Geology 22, 239-252 (1990).

[6] Samek D., L. Saracevic, A. Mihalj, N. Gradascevic, "Estimation of the External Gamma Dose Rate from Natural Radionuclides on the Territory of Bosnia and Herzegovina", Proceedings of the $5^{\text {th }}$ Symposium of the Croatian Radiation Protection Association, Stubicke Toplice, 2003, edited by I.C. Bronic, S. Miljanic and B. Obelic (HDZZ-CRPA, Zagreb, 2003) p. 296-301.

[7] United Nations Scientific Committee on the Effects of Atomic Radiation (UNSCEAR), Sources, Effects and Risk of Ionizing Radiation (Report to the General Assembly, with Scientific Annexes, United Nations, New York, 2000). 